\title{
Strengthening Human Security Through Para Diplomacy in Indonesia
}

\author{
Fadhlan Nur Hakiem $^{1 *}$, Ida Susilowati ${ }^{1}$ \\ ${ }^{I}$ Department of International Relations, University of Darussalam Gontor, Ponorogo, Indonesia \\ *Corresponding author. Email: fadhlanhakiem@unida.gontor.ac.id
}

\begin{abstract}
This research intended to explain how strengthening human security could be done by Para diplomacy which carried out by sub-state actors in Indonesia. Globalization is driving significant changes in international relations. The impact of these conditions is the increase in the importance of human security and the increasing of sub-state role in international cooperation. Local government is a sub-state actor who plays a significant role. The study used qualitative research methods. The research was conducted by descriptiveanalytical technique. To collect the data, this study used interview and literature studies. Data analysis was done through three stages, namely data reduction, data presentation, and concluding. This research shows that the practice of Para diplomacy by local governments as sub-state actors in Indonesia was able to contribute to the strengthening of human security. Strengthening human security was primarily related to economic security. The conclusion of this study explained that Para diplomacy has a strategic role in strengthening human security. However, the implementation of international cooperation by sub-state actors experienced several obstacles that caused the strengthening of human security was not running as optimal as the arrangement.
\end{abstract}

Keywords: human security, para diplomacy, international cooperation, local government

\section{INTRODUCTION}

Globalization is driving significant changes in international relations. Appadurai states that globalization is driving changes in five aspects, namely technoscapes, mediascapes, financescapes, ethnoscapes, and ideascapes [1]. These changes have an impact on contemporary relations between countries. Relations between countries encountered interdependence, which made countries need each other higher than before. Besides, international relations are no longer dominated by state actors. Non-state actors can play as important as the state. These conditions open up opportunities for new actors including sub-state actors to play a role in contemporary international relations.

International relations in the traditional form see that international cooperation is the authority of the state. But through globalization, international cooperation can no longer be monopolized by the state. Sub-state actors such as cities and other local governments could be important actors in international cooperation. The role of sub-state actors especially cities becomes important because those cannot be separated from global urbanization. According to UNHabitat explained by Tavares, $75 \%$ of the world's population will live in cities by $2050.80 \%$ of global economic output is produced by cities [2].

In Indonesia, changes in international relations also occur because they are supported by changes in domestic politics. The end of the new order brought significant changes to the Indonesian political system and government. The Implementation of regional autonomy is one of the fundamental changes. The enactment of Regional Autonomy gives enormous authority to the local government. This authority provides space for the local government to conduct international cooperation.

International cooperation undertaken by local governments in Indonesia illustrates the changes in contemporary international cooperation. International cooperation is no longer under the arm of the central government. This power has been distributed to sub-national actors, including local governments in Indonesia.

According to the Indonesian Ministry of Foreign Affairs Treaty Room, there is more than 71 international cooperation that has been carried out by the local government [3]. There are three provinces of Indonesia that very active in conducting international cooperation, namely Jakarta, West Java, and Yogyakarta. These provinces have various international cooperation with the foreign local government and private sector. Mukti said that Yogyakarta province had 13 international cooperation until 2013 [4]. International cooperation which carried out by sub-state actors often referred to as Para diplomacy. Para diplomacy is an abbreviation of parallel diplomacy means beside, near, alongside, subsidiary or assistant [2]. Based on this meaning, Para diplomacy is defined as international activities that are conducted by sub-state actors who support, supplement, improve, duplicate, or challenge diplomacy which done by the state [2]. According to Mukti, Para diplomacy is behavior that refers to "the behavior and capacity of conducting foreign relations with foreign parties carried out by sub-state entities in the context of their specific interests" [4].

The big authority owned by the local government as a substate actor generates a great responsibility for the local government. Local governments required to play a more active role in solving various problems. Maksum and Surwandono said that Para diplomacy is a policy that 
became a model for local governments to improve the regional economy through international networks [5]. Para diplomacy conducted by local governments provide opportunities for cooperation, especially in the economic fields such as trade and investment. Although it has the potential to contribute to the local development, Para diplomacy frequently only became ceremonial activities. Para diplomacy usually ended in some documents more than implemented as programs.

Para diplomacy is also considered capable of encouraging the success of sustainable development. Sub-state actors, such as the city government, have a strategic role in supporting the achievement of sustainable development [6]. Para diplomacy can be an effective mechanism as efforts to make the development agenda successful [6]. The government of the cities can help the success of development because the city is the main key in providing public services that have a certain quality for the people [6].

The demand for Para diplomacy to contribute to social welfare is increasingly high. International cooperation undertaken by local governments is expected to have a positive impact on society. In addition to economic cooperation and sustainable development that has been previously mentioned, one important aspect for the fulfillment of the welfare of society is human security. Human security is a security concept developed by the United Nations. Human security guarantees security from the threat of fear and the threat of inadequacy. Strengthening the aspects of human security will encourage community welfare.

Strengthening human security is an important agenda to encourage sustainable and equitable development. Sub-state actors, in this case, we refer to local government can participate in encouraging reinforcement of human security aspects. Various studies related to Para diplomacy do not mention a lot about the relationship between human security and the practice of Para diplomacy undertaken by sub-state actors.

Based on this reality, the research is expected to be able to explain about strengthening aspects of human security through the role of sub-state actors. Besides, this research is also focused to explain the practice of Para diplomacy by local governments in Indonesia. It aimed at explaining the detail of the strategic role of local government in strengthening human security aspects.

\section{METHODOLOGY}

This research used qualitative research methods. Qualitative methods used to understand the social phenomenon descriptively through various questions using scientific methods [7]. This is analytical descriptive research. The research attempted to analyze various information from data that has been obtained from primary and secondary sources. The data explanation followed by the research object analysis. Data collection techniques used in this study were interviews and literature studies. Interviews were conducted to obtain in-depth information about the object of research. While the literature studies tried to obtain additional information, which supports the data analysis.
Data analysis was used by researchers to answer research questions or test hypotheses that have been stated previously. Data analysis was the process of simplifying data and presenting data by grouping them in a form that easier to read and interpret [7]. According to Miles and Huberman in Silalahi, data analysis activities consist of three sequences of activities. Those were reducing data, presenting data, and making conclusions [8].

\section{RESULTS AND FINDINGS}

\subsection{International Cooperation of the Yogyakarta Province Government}

The Yogyakarta Province was one of the leading local governments that have been implemented Para diplomacy. Yogyakarta province held the first Para diplomacy in 1985. This province collaborated with Kyoto Prefecture, Japan. Yogyakarta Province and Kyoto's collaborated on some fields included arts, culture, education, science and technology, tourism, and industry. Yogyakarta Province had 31 international cooperation until 2019 [9]. The majority of cooperation implemented in the reform era. The cooperation conducted in the reformation era was $86 \%$ of the total international cooperation that had been initiated. The following list was international cooperation that has been carried out by the Yogyakarta Province Government until 2019:

Table 1 International Cooperation in Yogyakarta Province

\begin{tabular}{|c|c|c|}
\hline No & Province / State & Year \\
\hline 1 & Kyoto Prefecture / Jepang & $\begin{array}{l}1985, \quad 2010, \\
2015\end{array}$ \\
\hline 2 & Ismailia / Mesir & 1990,1991 \\
\hline 3 & California / AS & 1997 \\
\hline 4 & $\begin{array}{l}\text { East Asia Tourism Organization } \\
\text { Forum }\end{array}$ & 1999 \\
\hline 5 & Land Tyrol / Austria & 1999 \\
\hline 6 & $\begin{array}{l}\text { Gyeongsangbuk-do / Korea } \\
\text { Selatan }\end{array}$ & $\begin{array}{l}2005 \\
2015\end{array}$ \\
\hline 7 & Surugawa Miyagawa & 2003,2008 \\
\hline 8 & Karsruhe University / Jerman & $\begin{array}{l}2004,2005, \\
2008,2010\end{array}$ \\
\hline 9 & $\begin{array}{l}\text { Chungcheongnam-do / Korea } \\
\text { Selatan }\end{array}$ & 2004 \\
\hline 10 & Medical Peace Foundation & 2007 \\
\hline 11 & International Finance Corporation & 2007 \\
\hline 12 & Chiang Mai / Thailand & 2007 \\
\hline 13 & Gang-won / Korea Selatan & 2008,2009 \\
\hline 14 & HNA Group / Cina & 2009 \\
\hline 15 & $\begin{array}{l}\text { East Asia Local and Regional } \\
\text { Congress }\end{array}$ & 2010 \\
\hline 16 & Saint-Petersburg / Russia & 2010 \\
\hline 17 & Juma' Al Majid / UEA & 2011 \\
\hline 18 & Dongbu Engineering & 2012 \\
\hline 19 & Kayseri / Turki & 2013 \\
\hline 20 & Shanghai / Cina & 2014 \\
\hline 21 & Shanghai Theater Academy / Cina & 2016 \\
\hline
\end{tabular}


regional governments. Those are cooperation with the government of Victoria-Australia, Yamanashi Prefecture and Kyoto in Japan, Gangwon Province and Gyeongsangbuk-do of South Korea [10].

\subsection{Constraints of Yogyakarta Province Cooperation}

The Government of Yogyakarta Province relatively has much international cooperation compared to other local governments in Indonesia. Yogyakarta Province together with West Java and Jakarta became the leading region in conducting international cooperation or more popularly called Para diplomacy. However, the implementation of the Para diplomacy in Yogyakarta Province experienced several obstacles. International cooperation was undertaken by Yogyakarta province often ended up at the Memorandum of Understanding (MoU) stage. In the end, cooperation could not be implemented maximally by the government.

There were several obstacles found in the field which hamper the implementation of international cooperation by Yogyakarta Province. Those were budget efficiency, bureaucracy, leadership, and cooperation partners [10].

Firstly, budget efficiency. This was a problem because the budget had a significant influence on determining a policy. Local governments have to calculate budgets efficiently and effectively so that the policies could be implemented as effective as the formulation. International cooperation had not seen as a significant opportunity for community development. It was only seen as a burden on local budgets. Secondly, bureaucrats. Bureaucrats considered to be another obstacle in international cooperation because they had the main role in implementing policies. Bureaucrats were often less concerned with international cooperation undertaken by the local governments. This happened because international cooperation considered a more workload of bureaucrats in the local government environment.

Thirdly, leadership. Leadership had an influential role in the implementation of government policy in Indonesia. In the process of planning and implementing international cooperation, the leader's vision and mission influenced foreign cooperation.

Finally, international cooperation partners. The continuity of international cooperation would influence by colleagues who carry out international cooperation. The failure of the Yogyakarta Province cooperation with the state of California and Tyrol triggered by a significant gap between the two regions as a collaborative partner with Yogyakarta Province.

\subsection{Yogyakarta Province Cooperation and Strengthening Human Security}

The international cooperation of Yogyakarta province was an example of Para diplomacy practice. Para diplomacy had many interests that specifically become the goal of sub-state entities in conducting international relations. The most important phase of Para diplomacy is the achievement of the sub state's interests. The main objective of the regional government as a sub-state in conducting cooperation is to 
increase local development. One aspect that can support the increasing of local development is human security.

Human security was a concept that developed after the cold war. This concept emphasizes the fulfillment of basic human needs, those are freedom from fear and freedom from want. Wardoyo mentioned that human security is security through development [11].

According to UNDP human security can be defined as Human security can be said to have two main aspects. It means, first, safety from such chronic threats as hunger, disease, and repression. And second, it means protection from sudden and hurtful distractions in the patterns of daily life - whether I am home, in jobs or communities. Such threats can exist at all levels of national income and development [12].

Based on that explanation, there are seven elements of human security namely economic, food, health, environment, politics, individuals, and community [12]. International cooperation undertaken by the Yogyakarta Province covered various aspects, as illustrated in figure 1 . Cooperation conducted in various fields that has the potential to support the strengthening of human security aspects. However, it is not all aspects of human security that can be strengthened by the international cooperation of Yogyakarta Province. The practice of Para diplomacy by Yogyakarta Province only reinforces several aspects of human security. Para diplomacy can strengthen human security, especially in the aspect of economic security. This is illustrated in the implementation of the cooperation between Yogyakarta Province and Yamanashi Prefecture, Japan and Gyeongsangbuk-do Province, South Korea.

a. Yogyakarta Province Government collaborated with Yamanashi Prefecture in 2015. Both parties agreed to a Letter of Intent in 2015 and then continued with the signing of the MoU in 2016. The implementation of the cooperation focused on strengthening efforts in the agricultural sector. In 2018 and 2019, there were several activities as a result of the implementation of the cooperation between the two parties. The cooperation between two parties that had been implemented was:

b. There was one intern sent from the local unit of Ngipiksari to Yamanashi for 2 months;

c. Technical assistance from Yamanashi for the cultivation of grapes, strawberries, and flowers in Yogyakarta;

d. Strawberry cultivation in Ngipiksari;

e. Grapes cultivation Ngipiksari unit;

f. Strawberry cultivation in Srunen, Glagahharjo, Cangkringan, Sleman;

g. Grapes Cultivation in Kaling Tengah, Glagaharjo, Cangkringan, Sleman [13].

Through this international cooperation, Yogyakarta Province hopes to get a better profit. Some programs expected to have some major contributions. They were grape and strawberry production, infrastructure assistance, grape, and strawberry cultivation technology, and training in grape and strawberry cultivation [13].

In addition to Yamanashi Prefecture, the cooperation which influenced on strengthening human security was the cooperation with Gyeongsangbuk-do, South Korea. After the signing of the Letter of Intent (LoI) and Memorandum of Understanding (MoU) in 2006, two parties conducted much international cooperation within the sister province framework. Various activities had been implemented, such as enhancing the capability of the Yogyakarta Province's apparatus. In the year 2006, there were Korean language class programs, special lessons and introduction to Korean culture [14]. Through this cooperation, Yogyakarta Province usually sends its representatives to Korea every year for 6 months to attend the Korean Language Training Program for Sister City Public Officials [14].

Another important cooperation between the two parties was the implementation of the Saemaul Undong program in Yogyakarta. The beginning of this program began in 2007 which was agreed upon was the signing of $\mathrm{MoU}$ in 2008. This program had been implemented in three districts in Yogyakarta, Kulon Progo Bantul, and Gunungkidul. This pilot project program carried out in Kampung Village, Ngawen, Gunungkidul in 2008 [14]. The Saemaul Undong program includes various activities such as:

1. Village infrastructure development (construction of community hall and village road)

2. Improving the quality of life (establishment of community well for water supply)

3. Increasing income (dairy cows aliment)

4. Volunteer activities (free health services)

5. Introduction to Korean culture

Those implementations of international cooperation illustrated very clearly that strengthening human security can be done through the practice of Para diplomacy. Both partnerships provided a very large portion of community empowerment. This empowerment would greatly affect the strengthening of human security because human security determined by the success of the development. Empowerment of the community in the agricultural sector and community economic development through pilot villages can ultimately increase the security of the community's economy and will prevent the community from the threat of limitations (freedom from want).

However, it was not all international cooperation or Para diplomacy practices by local governments that could affect strengthening human security. Some forms of cooperation have less impact. This was reflected in the cooperation between Yogyakarta Province and the Victorian Government, Australia. Yogyakarta and Victoria developed a cooperation that emphasized the cultural sector [15]. Therefore, it was difficult to measure the impact directly on strengthening human security.

\section{CONCLUSION}

Human security is a fundamental thing and must be fulfilled. Every citizen has the right to secure from fear and limitations. Security responsibility aspects were no longer become the main area of the state. However, other actors including sub-states have the same responsibilities as the state for fulfilling human security. Local government as a form of sub-state actor has a strategic role in encouraging the strengthening of human security. However, as illustrated in the cooperation by Yogyakarta Province, the implementation of Para diplomacy itself had not been running optimally due to various obstacles encountered. These constraints had to be resolved immediately because Para diplomacy has significant potential in supporting 
development. Strengthening human security could be done through Para diplomacy practices that oriented towards community empowerment programs, as illustrated in the Yogyakarta Province cooperation program with Yamanashi Prefecture and Gyeongsangbuk-do Province. Para diplomacy practices that were not oriented towards community empowerment would not have any impact on the fulfillment or strengthening of human security. Through programs oriented to empowering the community, human security could be strengthened

\section{REFERENCES}

[1] A. Appadurai, "Disjuncture and Difference in the Global Cultural Economy," Theory, Cult. Soc., vol. 7, no. 2, pp. 295-310, 1990.

[2] R. Tavares, Paradiplomacy; Cities and States as Global Players. New York: Oxford University Press, 2016.

[3] "Data Perjanjian Luar Negeri." [Online]. Available: https://treaty.kemlu.go.id/search. [Accessed: 15-Sep2019].

[4] T. A. Mukti, Paradiplomacy Kerjasama Luar Negeri Oleh Pemda Di Indonesia. Yogyakarta: Phinisi Press, 2013.

[5] A. Maksum and Surwandono, "The Dynamics of Paradiplomacy Practices in the 'Frontier' Areas in Indonesia," J. ASEAN Stud., vol. 6, no. 2, pp. 137-154, 2018.
[6] N. Isnaeni, "Peran Strategis Pemerintah Daerah dalam Kerja Sama Internasional untuk Pembangunan Berkelanjutan," Glob. Strateg., vol. 1, no. 7, pp. 123138, 2012.

[7] L. J. Moleong, Metodologi Penelitian Kualitatif. Bandung: Rosda, 2014.

[8] U. Silalahi, Metode Penelitian Sosial, 3rd ed. Bandung: Rafika Aditama, 2012.

[9] "Kerjasama." [Online]. Available: https://jogjainvest.jogjaprov.go.id/kerjasama.html. [Accessed: 20-Sep-2019].

[10] J. Hariyono, "Kerjasama Luar Negeri Provinsi Yogykarta,” 2019. .

[11] B. Wardoyo, Perkembangan, Paradigma, dan Konsep Keamanan Internasional dan Relevansinya Untuk Indonesia. Klaten: Nugra Media, 2015.

[12] UNDP, "Human Development Report 1994,” New York, 1994.

[13] "Kerjasama DIY - JEPANG." [Online]. Available: https://jogjainvest.jogjaprov.go.id/diy----jepang.html. [Accessed: 20-Sep-2019].

[14] "Kerjasam DIY - Korea." [Online]. Available: https://jogjainvest.jogjaprov.go.id/diy----korea.html. [Accessed: 20-Sep-2019].

[15] "Kerjasama DIY - Australia." [Online]. Available: https://jogjainvest.jogjaprov.go.id/diy----australia.html. [Accessed: 20-Sep-2019]. 